\title{
Effects of pH on Fertilization and the Hatching Rates of Far Eastern Catfish Silurus asotus
}

\author{
Yang Gao, Sun-Gyu Kim and Jeong-Yeol Lee* \\ Department of Aquaculture and Aquatic Science, Kunsan National University, Gunsan 573-701, Korea
}

\begin{abstract}
In this experiment, we examined the survival, fertilization, hatching times, and hatching rates of Far Eastern catfish Silurus asotus at $\mathrm{pH}$ ranging from 2 to 13 under laboratory conditions. Eggs could be fertilized at $\mathrm{pH} 3-12$. In a hatching experiment, mortality was first observed at pH 13, when all fertilized eggs died within $8 \mathrm{~min}$, followed by $\mathrm{pH} 2$ (30 min), pH 12 (60 min), pH 3 (4 h), and $\mathrm{pH} 11$ (5 h). Hatching only occurred at $\mathrm{pH} 4-10$, with the highest hatching rate at $\mathrm{pH} 7$ (52\%) and the lowest at $\mathrm{pH} 10(24 \%)$. Hatching rates in acid solutions were higher than in alkaline solutions, although the difference was not significant. Hatching was first observed at $\mathrm{pH} 10$, beginning $27 \mathrm{~h}$ after fertilization and ending at the $31 \mathrm{~h}$. A clear difference was observed between hatching times, ranging from 31 to $64 \mathrm{~h}$ and increasing in order with descending $\mathrm{pH}$.
\end{abstract}

Key words: $\mathrm{pH}$, Fertilization rate, Hatching rate, Silurus asotus, Far Eastern Catfish

\section{Introduction}

$\mathrm{pH}$ is the main factor affecting water quality. Extreme $\mathrm{pH}$ negatively affects fish growth and reproduction (Zweig et al., 1999) and even causes massive mortalities in fish culture. Sensitivity to extreme $\mathrm{pH}$ conditions varies according to fish species and age, with fish showing lower tolerance at the embryonic and larval stages (Lloyd and Jordan, 1964). The fertilization of most fish species is unsuccessful at water $\mathrm{pH}$ lower than 4.0 (Peterson et al., 1982). The fertilization success of Atlantic salmon Salmo salar decreased to zero with a decrease in $\mathrm{pH}$ from 5.0 to 4.0 (Daye and Glebe, 1984), and an increase in salmonid egg mortality due to fertilization in acidic water (pH 4.6) was also found by Carrick (1979) and Parker and McKeown (1987). Relatively little is known about the effects of alkaline discharges on the fertilization and hatch rates of fish, which may reflect the lesser importance of the problem. However, in cases in which high $\mathrm{pH}$ is caused by the vigorous photosynthetic activity of aquatic plants, accompanying high temperatures and supersaturation of dissolved gases (together with other factors) may also contribute to fish mortality to a greater or lesser extent, making a correlation between mortality and $\mathrm{pH}$ data alone quite difficult.

Generally, the effect of low $\mathrm{pH}$ on fish fertilization and hatching is not often a subject of research (Sayer et al., 1993) except in salmonids. Many studies have been made on the effects of acidification on the fertilization and hatching of salmon and trout, but such studies on Far Eastern catfish Silurus asotus had not been conducted. Therefore, in this study, we investigated the effects of a wide range of $\mathrm{pH}$ on the mortality, fertilization, and hatching rates of catfish eggs.

\section{Materials and Methods}

\section{Preparation of pH solutions}

The water used was groundwater with a $\mathrm{pH}$ of 7.34, which also served as the control water. The study was conducted at the aqua farm of Kunsan National University. pH solutions
Open Access http://dx.doi.org/10.5657/FAS.2011.0417

This is an Open Access article distributed under the terms of the Creative Commons Attribution Non-Commercial License (http://creativecommons. org/licenses/by-nc/3.0/) which permits unrestricted non-commercial use, distribution, and reproduction in any medium, provided the original work is properly cited.
Received 10 October 2011; Revised 10 November 2011; Accepted 20 November 2011

*Corresponding Author

E-mail: yjeong@kunsan.ac.kr 
ranging from 2 to 13 were adjusted using sodium hydroxide and hydrochloric acid. Five milliliters of $\mathrm{pH}$ solutions was added to Petri dishes for the observation of fertilization. For the hatching experiment, $200 \mathrm{~mL}$ of $\mathrm{pH}$ solution was added to a $400-\mathrm{mL}$ beaker, and solutions were aerated with an air pump to ensure sufficient dissolved oxygen (above $7 \mathrm{mg} / \mathrm{L}$ ). Temperature was maintained at $23.5 \pm 1^{\circ} \mathrm{C}$ and $\mathrm{pH}$ was measured with a Mettler Toledo MP-220 (Mettler-Toledo $\mathrm{GmbH}$, Switzerland). $\mathrm{pH}$ was tuned every hour and the solutions were wholly changed every $6 \mathrm{~h}$ during all experimental periods. Fertilization and hatching experiments were performed in triplicate for each $\mathrm{pH}$ level.

\section{Egg and sperm collection}

The experiment was performed at the aqua farm of Kunsan National University. Three-year-old brood fish were selected and kept isolated in holding tanks. Spawning was induced in female brood fish using intraperitoneal injections of human chorionic gonadotropin at the rate of $10,000 \mathrm{IU} / \mathrm{kg}$ body weight. These fish were then stocked for $12 \mathrm{~h}$ at a water temperature of $28 \pm 0.5^{\circ} \mathrm{C}$. Twelve hours later, eggs were stripped into a dry bowl. Sperm were obtained through surgical removal of the testis. Adherent tissue was dissected away and the testes were pooled in physiological saline. Some of the stripped eggs were fertilized immediately with milt after sperm activation was initiated by the addition of water and stocked in an incubator. Sperm from one male were used to fertilize eggs from one female. The remaining eggs were stocked in a dry bowl and sperm were stocked in physiological saline for the fertilization experiment.

\section{Fertilization and hatching rates}

To observe the fertilization rate, 50 eggs were placed into the prepared $5 \mathrm{~mL} \mathrm{pH}$ solutions; sperm were injected into the dish and mixed equably, and after about $1 \mathrm{~min}$ of gentle stirring, fertilization could be checked under a dissection microscope (10 100× magnification). Fertilization membranes formed immediately when an egg was fertilized so we could use them as a standard to determine whether such an event occurred. Fertilization rates were calculated as the number of total eggs divided by the number of fertilized eggs.

To determine the hatching rate, 50 fertilized eggs were selected from the incubator and placed randomly into the 200 $\mathrm{mL}$ prepared $\mathrm{pH}$ solutions. Mortalities and hatching rates were then recorded during the experimental period. Eggs were considered dead when parts of the content turned opaque and white. Dead eggs were counted and removed to prevent fungal growth. Hatching was defined as the rupture of the egg membranes by the tail. The hatching rate was determined as the proportion of hatched eggs to total eggs. Hatching time was recorded as the time span between fertilization and the hatching of the last egg.

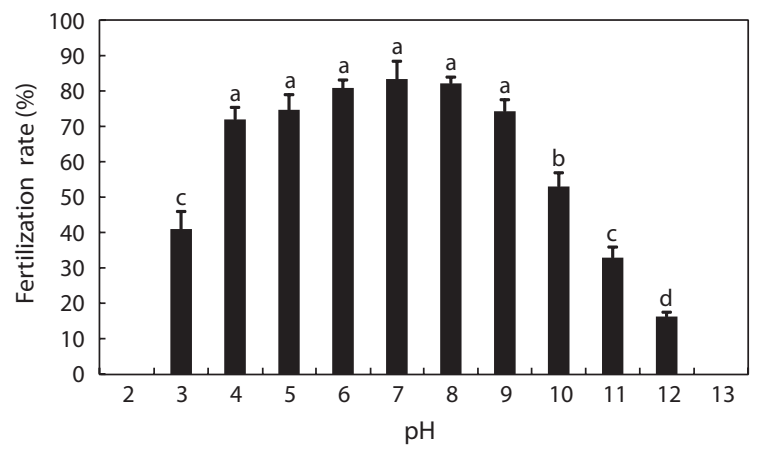

Fig. 1. Fertilization rate at different $\mathrm{pH}$ levels. Mean $\pm \mathrm{SD}$ with different letters are significant different based on ANOVA $(P<0.05)$.

\section{Statistical analysis}

Data were analyzed using SPSS version 16.0 (SPSS Inc., Chicago, IL, USA). One-way analysis of variance (ANOVA) was used to compare the mean values at different $\mathrm{pH}$ levels. $P<0.05$ was considered to indicate a significant difference.

\section{Results and Discussion}

In this experiment, catfish eggs were fertilized at $\mathrm{pH} 3-12$, as shown in Fig. 1. Fertilization rates from $\mathrm{pH} 4$ to 9 were above $70 \%$ and obviously higher than those at $\mathrm{pH} 3,10,11$, and 12 . The fertilization rates generally declined with decreasing acid concentrations and increasing alkalinity concentrations. No fertilization occurred at $\mathrm{pH} 2$ or 13 . The decrease in fertilization success may have been due to the effects of acidic water either on spermatozoa motility or on the eggs. We observed that egg membranes dissolved at $\mathrm{pH} 2$, although at $\mathrm{pH}$ 13 , eggs became opaque and white in a few minutes; we, however, did not notice the motility of spermatozoa. According to Daye and Glebe (1984), the motility time of Atlantic salmon spermatozoa decreased from $\mathrm{pH} 7.0$ to 4.0 , around which no motility was found after a lag of $20 \mathrm{~s}$. The proportion of motile spermatozoa of brook trout decreased as the $\mathrm{pH}$ was reduced from 5.0 to 3.5 and completely ceased at $\mathrm{pH} 3$ (St-Pierre and Moreau, 1987). Similar findings were reported for alkaline conditions. The sperm of common carp had a lower period of motility when the $\mathrm{pH}$ value of the water was raised to between 8.2 and 9.5, and $\mathrm{pH}$ values above 9.0 were found to be lethal (Elster and Mann, 1950). In our experiment, eggs could be fertilized at $\mathrm{pH} 3-12$. This was a considerably wide range compared to other fish species, suggesting that catfish eggs were more tolerant of extreme $\mathrm{pH}$ conditions. However, in $\mathrm{pH}$ 12,11 , and 3 solutions, the fertilized eggs did not survive long, all dying within $1 \mathrm{~h}, 5 \mathrm{~h}$, and $4 \mathrm{~h}$, respectively.

The survival rates of fertilized eggs at different $\mathrm{pH}$ levels are shown in Fig. 2. Mortality was first observed in $\mathrm{pH} 13$ solutions, with all eggs dying within $8 \mathrm{~min}$. At $\mathrm{pH} 2$, embryonic 


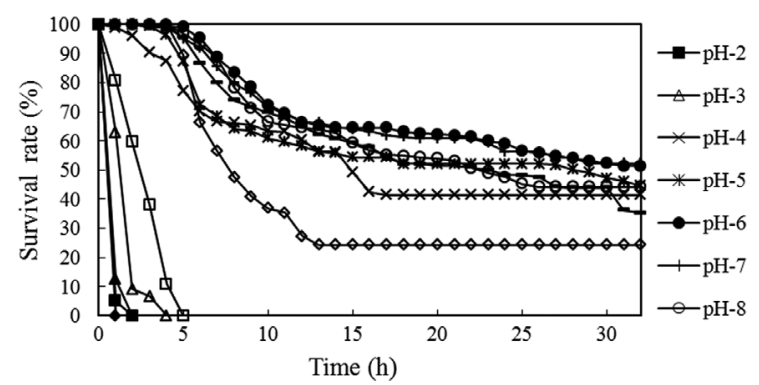

Fig. 2. Survival rate at different $\mathrm{pH}$ levels.

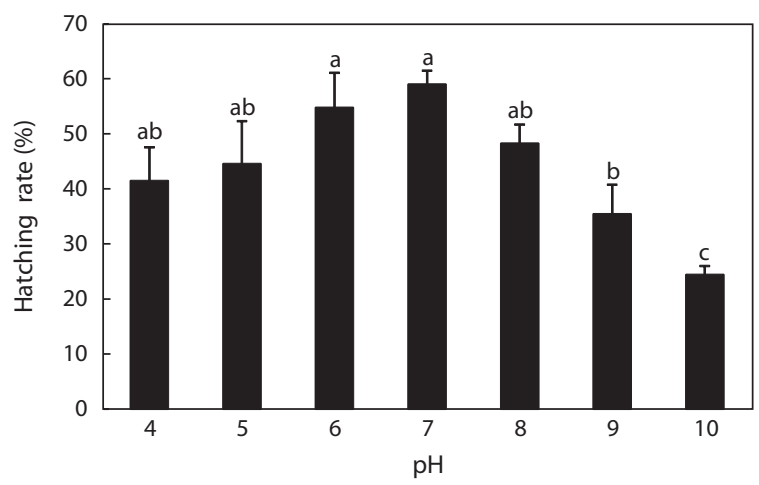

Fig. 3. Hatching rate at different $\mathrm{pH}$ levels. Mean \pm SD with different letters are significant difference based on ANOVA $(P<0.05)$.

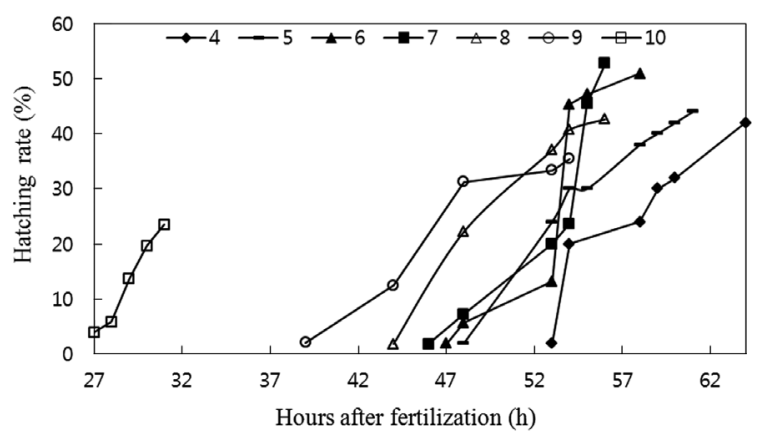

Fig. 4. Hatching time at different $\mathrm{pH}$ levels.

development stopped completely and all eggs died within 30 min. Cleavage occurred at $\mathrm{pH} 12$ and some eggs developed to the 2-cell stage, but all eggs died in $1 \mathrm{~h}$. Eggs started dying 60 min after fertilization in $\mathrm{pH} 3$ solutions. Two-thirds of the eggs died before entering the 4-cell stage, and all eggs died within $4 \mathrm{~h}$. At pH 11, most eggs died before the morula stage and all died within $5 \mathrm{~h}$ postfertilization. Mortality was high in the first $15 \mathrm{~h}$ in these solutions, after which time the death rate became low. The period of sensitivity to acidity and alkalinity appeared to be the first $5 \mathrm{~h}$ after fertilization. This phenomenon has also been reported for other species of fish such as Cyprinus carpio (Oyen et al., 1991), Stizostedion vitreum, Catostomus commersoni, Coregonus clupeaformis, and Not- ropis cornutus (Holtze and Hutchinson, 1989). Mortality in $\mathrm{pH}$ 4-10 solutions was higher during the first $15 \mathrm{~h}$ and became low thereafter, indicating that eggs are susceptible to acid exposure immediately after fertilization until the membranes have hardened. Cykowska and Winnicki (1972) reported that egg membrane strength increased sevenfold in the first $12 \mathrm{~h}$ after fertilization and had increased by 15 times after $24 \mathrm{~h}$. After hardening, the chorion and the plasma membrane form a resistant barrier to protect the developing embryo from external media.

Hatching rates are shown in Fig. 3. Hatching occurred at $\mathrm{pH}$ 4-10, but the hatching rate was low, even in the control with the highest hatching rate of $52 \%$, followed by $\mathrm{pH} 6, \mathrm{pH} 5, \mathrm{pH}$ $8, \mathrm{pH} 4, \mathrm{pH} 9$, and $\mathrm{pH} 10$. No obvious difference was seen between the control and $\mathrm{pH} 4,5,6$, or 8 solutions, but control rates were significantly higher than those in $\mathrm{pH} 9$ and 10 solutions. Hatching rates in acid solutions were higher than those in alkaline solutions. In fact, this was supposed to be a wide $\mathrm{pH}$ range for hatching compared to other fish species. Many reports of hatching failure under such acidic conditions have been published. For example, Trojnar (1977) reported that deformations and death of white sucker C. commersoni embryos occurred at pH 5.0. Mount (1973) found that deformations of fathead minnow Pimephales promelas eggs took place at $\mathrm{pH}$ 5.9. Johansson and Milbrink (1976) reported that the embryonic development of roach and perch stopped at a $\mathrm{pH}$ lower than 4.6.

However, fewer reports have described the tolerance of fish to alkaline solutions, and generally, the $\mathrm{pH}$ range of 5-9 is accepted as harmless to fish. Krishna (1953) found that for trout eggs and alevins, mortalities occurred above a $\mathrm{pH}$ value of 9.0, but the length of exposure was not given. The various developmental stages of turbot eggs showed different sensitivities to alkaline waters, with the most sensitive stage being that of embryo segmentation, when a $\mathrm{pH}$ value of 8.0 killed half of the eggs (Volodin, 1960). Resistance increased after this stage, but even at $\mathrm{pH}$ 9.0, hatching was delayed. This was different from the results of our experiment, wherein eggs hatched in alkaline solutions, even at $\mathrm{pH} 10$, with a hatching rate of about $24 \%$ (Fig. 3), followed by pH 9 (35\%) and pH 8 (48\%). These data suggested that catfish eggs were less sensitive to acid and alkaline stress compared to those of the above-mentioned fish species.

A significant difference was observed between hatching times, as shown in Fig. 4. Hatching time increased with decreasing $\mathrm{pH}$ values. Although the hatching rate was lowest at $\mathrm{pH} 10$, the hatching time was the shortest, with hatching beginning $27 \mathrm{~h}$ after fertilization and ending at the $31 \mathrm{st} \mathrm{h}$. The eggs in $\mathrm{pH} 4$ solutions did not start hatching until $53 \mathrm{~h}$ after fertilization, and $64 \mathrm{~h}$ were required for all eggs to hatch. In this experiment, hatching time was longer than those recorded under field conditions, which may be attributable to experimental conditions being less stable than field conditions. The eggs in our experiment seemed to suffer more artificial stress 
from factors such as $\mathrm{pH}$ adjustment and water change. The delay in hatching time, as observed in catfish, has been frequently been noted in eggs of other fish species. Rask (1983) found that eggs of Perca fluviatilis reared at $\mathrm{pH} 4$ showed a delay in hatching time relative to that of the control. Delays in hatching time resulting from acid stress were also found for P. promelas (Mount, 1973), Salmo trutta fario (Brown and Lynam, 1981), and brook trout Salvelinus fontinalis (Swarts et al., 1978). This may imply that eggs in acidic water were viable to predation for a longer period than eggs in neutral water. However, contradictory observations have even been reported for salmon species. For example, Daye and Garside (1979) found no influence of acid stress on the rate of development of Atlantic salmon at pH 6.8-3.7. Menendez (1976) also found no such effects for $S$. fontinalis. Trojnar (1977) even recorded more rapid development of $S$. fontinalis at $\mathrm{pH}$ levels lower than 5. However, in this study, hatching time in alkaline solutions was faster than those in the neutral and acid solutions, especially under $\mathrm{pH} 10$, when hatching occurred in only $31 \mathrm{~h}$. Few reports exist on the hatching times of eggs under alkaline conditions, and this accelerated hatching was first observed in the present experiment. However, the reason for it remains unclear, and further study is still needed in this field.

\section{Acknowledgments}

The authors wish to acknowledge the financial support of the Fisheries Science Institute of Kunsan National University made in the program year of 2011 .

\section{References}

Brown DJA and Lynam S. 1981. The effect of sodium and calcium concentrations on the hatching of eggs and the survival of the yolk sac fry of brown trout, Salmo trutta L. at low pH. J Fish Biol 19, 205-211.

Carrick TR. 1979. The effect of acid water on the hatching of salmonids eggs. J Fish Biol 14, 165-172.

Cykowska C and Winnicki A. 1972. Embryonic development of the Baltic sea trout (Salmo trutta) in buffer solutions. Acta Ichthyol Pisca 2, 3-12.

Daye PG and Garside ET. 1979. Development and survival of embryos and alevins of the Atlantic salmon, Salmo salar L., continuously exposed to acidic levels of $\mathrm{pH}$, from fertilization. Can J Zool 57, 1713-1718.

Daye PG and Glebe BD. 1984. Fertilization success and sperm motility of Atlantic salmon (Salmo salar L.) in acidified water. Aquaculture 43, 307-312.

Elster H and Mann H. 1950. Experimentelle Beitrage zur Kenntnis der
Physiologie der Befruchtung bei Fischen. Arch Fisch Wiss 2, 4972.

Holtze HK and Hutchinson NJ. 1989. Lethality of low pH and Al to early life stages of six Fish species inhabiting Precambrian Shield waters in Ontario. Can J Fish Aquat Sci 46, 1188-1202.

Johansson N and Millbrink G. 1976. Some effects of acidified water on the early development of roach (Rutilus rutilus L.) and perch (Perca fluviatilis L.). J Am Water Resour Assoc 12, 39-48.

Krishna D. 1953. Effect of changing $\mathrm{pH}$ on developing trout eggs and larvae. Nature 171, 434.

Lloyd R and Jordan DHM. 1964. Some factors affecting the resistance of rainbow trout (Salmo gairdnerii Richardson) to acid waters. Air Water Pollut 8, 393-403.

Menendez R. 1976. Chronic effects of reduced pH on brook trout (Salvelinus fontinalis). J Fish Res Board Can 33, 118-123.

Mount DI. 1973. Chronic effect of low $\mathrm{pH}$ on fathead minnow survival, growth and reproduction. Water Res 7, 987-993.

Oyen FGF, Camps LECMM and Wendelaar Bonga SE. 1991. Effect of acid stress on the embryonic development of the common carp (Cyprinus carpio). Aquat Toxicol 19, 1-12.

Parker DB and McKeown BA. 1987. The effects of low pH on egg and alevin survival of kokanee and sockeye salmon, Oncorhynchus nerka. Comp Biochem Physiol C 87, 259-268.

Peterson RH, Daye PG, Lacroix GL and Garside ET. 1982. Reproduction in fish experiencing acid and metal stress. In: Acid Rain/ Fisheries: Proceedings of an International Symposium on Acidic Precipitation and Fishery Impacts in Northeastern North America, RE.(ed.), American Fisheries Society, Bethesda, MD, US, pp.177196.

Rask M. 1983. The effects of low pH on perch, Perca fluviatilis L. I. Effects of low $\mathrm{pH}$ on the development of eggs of perch. Ann Zool Fenn 20, 73-76.

Sayer MDJ, Reader JP and Dalziel TRK., 1993. Freshwater acidification: effects on the early life stages of fish. Rev Fish Biol Fish 3, 95-132.

St-Pierre M and Moreau G. 1987. Résistance et viabilité des gamètes d'Omble de fontaine, Salvelinus fontinalis, à différents pH. Hydrobiologia 153, 139-148.

Swarts FA, Dunson WA and Wright JE. 1978. Genetic and environmental factors involved in increased resistance of brook trout to sulfuric acid solutions and mine acid polluted waters. Trans Am Fish Soc 107, 651-677.

Trojnar JR. 1977. Egg hatchability and tolerance of brook trout (Salvelinus fontinalis) fry at low pH. J Fish Res Board Can 34, 575-579.

Volodin VM. 1960. Embryonic development of the autumn Baltic herring and their oxygen requirements during the course of development.Vopr Ikhtiol 7, 123-133.

Zweig RD, Morton JD and Stewart MM. 1999. Source Water Quality for Aquaculture: A Guide for Assessment. World Bank, Washington, DC, US. 